\title{
Toward Defect Engineering Strategies to Optimize Energy and Electronic Materials
}

\author{
Efstratia N. Sgourou ${ }^{1,2}$, Yerasimos Panayiotatos ${ }^{2}$ iD, Ruslan V. Vovk ${ }^{3}$ and \\ Alexander Chroneos $4,5, *$ \\ 1 Section of Solid State Physics, University of Athens, Panepistimiopolis Zografos, Athens 15784, Greece; \\ e_sgourou@hotmail.com \\ 2 Department of Mechanical Engineering, Piraeus University of Applied Sciences, Athens 12241, Greece; \\ gpana@puas.gr \\ 3 School of Physics, V. N. Karazin Kharkiv National University, 4 Svobody sq., Kharkiv 61000, Ukraine; \\ r.v.vovk@mail.ru \\ 4 Faculty of Engineering and Computing, Coventry University, Priory Street, Coventry CV1 5FB, UK \\ 5 Department of Materials, Imperial College London, London SW7 2BP, UK \\ * Correspondence: alexander.chroneos@imperial.ac.uk; Tel.: +30-69-7877-5320
}

Received: 3 June 2017; Accepted: 27 June 2017; Published: 30 June 2017

\begin{abstract}
The technological requirement to optimize materials for energy and electronic materials has led to the use of defect engineering strategies. These strategies take advantage of the impact of composition, disorder, structure, and mechanical strain on the material properties. In the present review, we highlight key strategies presently employed or considered to tune the properties of energy and electronic materials. We consider examples from electronic materials (silicon and germanium), photocatalysis (titanium oxide), solid oxide fuel cells (cerium oxide), and nuclear materials (nanocomposites).
\end{abstract}

Keywords: defect engineering; electronic materials; solid oxide fuel cells; nuclear materials; photocatalysis

\section{Introduction}

In the past few decades of the miniaturization of devices, the introduction of more structurally complicated materials in conjunction with demanding processing and operating conditions have made the study of defects in materials increasingly important [1-10]. There is no single recipe of how to treat materials and what is the optimum concentration of defects. In a material, some defects and dopants can have a beneficial impact and in a similar material the same defects can deteriorate its physical properties. For example, $n$-type dopants in silicon are necessary to form devices and do not readily interact with vacancies due to the low concentration of the latter. In isostructural germanium, $n$-type dopants are hard to contain as they diffuse aided by vacancies and it is hard to form $n$-doped regions [3]. The same arguments can apply to energy related materials (for example nuclear, fuel cell, and battery materials) for which there is presently a requirement to employ and/or form materials with better properties that will need to operate at more difficult conditions for longer periods of time.

Using defect engineering strategies is an efficient way to tune the physical properties and optimize materials for energy and electronic applications. Defect engineering strategies in essence use the differences that composition, structure, disorder, and strain can have on the physical properties of the material. It is impossible to highlight all the progress in the field and contain it in a single review. In the present review, we consider a range of applications and materials from nanocomposites to more traditional systems such as silicon and titanium dioxide aiming to demonstrate how the defect engineering strategies considered can be transferable to numerous systems and applications. 


\section{Advanced Materials for Nuclear Applications}

\subsection{Background}

About 70 years since Enrico Fermi et al. built the first nuclear reactor, nuclear power is once more in the spotlight. There is a need for the new generation of safer and more proliferation resistant reactors whose introduction would have the beneficial effect of lowering $\mathrm{CO}_{2}$ emissions due to electricity generation. Several high profile nuclear incidents have cast a shadow over the nuclear industry in the past. As a consequence, for nuclear power generation to have a bright future it will be necessary to allay fears regarding safety, proliferation, and the long term management of wastes. This, together with institutional inertia and the cost to develop new nuclear technologies may delay its progress. Atomic scale simulation techniques can accelerate the development of new nuclear materials and provide detailed information on their physical properties that cannot be easily assessed by experiments.

Nuclear energy is potentially important for the future energy mix given the need to address the increasing global energy demand and simultaneously reduce $\mathrm{CO}_{2}$ emissions [11-15]. Nuclear materials are subjected to extreme conditions and the detailed understanding of their properties often at the atomistic scale is necessary to ensure their high performance and more importantly their safety. The ever increasing computational power has allowed the investigation of the behaviour of nuclear materials with atomistic modeling techniques that were not available when most commercial reactors operating today were designed.

The efficiency of nuclear reactors can be increased via higher operating temperatures, increasing their lifetime and taking fuels to higher burn-ups. Additionally, the introduction of new materials such as thorium dioxide $\left(\mathrm{ThO}_{2}\right)$ or mixed oxide based nuclear fuels requires extensive investigation prior to their use in nuclear reactors [13]. The evolution of nuclear material properties under a range of conditions encountered in the harsh environments in which they operate can be a challenge for scientists.

Nuclear fission was observed in 1939 by Otto Hahn and Fritz Strassman. Following the bombardment of uranium with neutrons, they discovered two products with lighter nuclei, barium and lanthanum. Thereafter, Lise Meitner and Otto Frisch explained the phenomenon that is presently exploited in nuclear reactors to generate heat. This heat is in turn used to heat water into pressurized steam, which runs through turbines powering electrical generators.

Nuclear energy is acknowledged as a key component of the mix of energy sources to reduce greenhouse gas emissions and the dependence on fossil fuel. A main advantage of nuclear energy is its high energy density; that is, the quantity of energy derived from nuclear fuel is orders of magnitude larger than competitive energy sources such as fossil fuels. The nuclear facilities are rather compact and require far less land as compared with solar energy on wind energy installations producing the same power. Nuclear power has been an established and reliable source of electricity in numerous countries (for example, USA, France, UK, Russia, China) for many decades. The possibility of hydrogen production via an efficient centralised technology taking advantage of mainly off-peak electricity production is another possibility. Taking into consideration that there are still substantial reserves of uranium and that alternative fuels can also be used (thorium-based) there should be enough nuclear fuel for many decades.

There are also negative issues with nuclear energy associated with the negative public perception stemming from nuclear accidents, nuclear waste management, and proliferation issues. Nuclear accidents (for example Three Mile Island, Chernobyl, and Fukushima) have dealt a major blow to the nuclear industry and its reputation. Although nuclear energy results in far less casualties than other forms of energy generation, it is considered to be very perilous. This is due to some examples of poor nuclear waste management, its association with nuclear weapons, and the long half-life of extremely radiotoxic nuclear waste. 
To design and construct safer nuclear reactors for the coming decades, it is imperative to manufacture better nuclear materials. In particular, there is the requirement for radiation tolerant materials to store nuclear waste, advanced structural materials, and novel nuclear fuels.

\subsection{Radiation Tolerant Materials}

The safe storage of nuclear waste is considered as a prerequisite for public support. The construction of new reactors differs as compared to previous generations in that nuclear waste solutions including packaging materials and appropriate repositories must be thought of and identified as part of the initial design [16].

Nuclear waste management is a very difficult task due to the radiotoxicity and long half-lives of actinides and fission products. A feasible solution is to move nuclear waste to relatively stable geological formations. These repositories will be reinforced by barriers, for example corrosion-resistant cladding and compacted clay $[17,18]$. Identifying waste-packaging materials to host high-level waste (HLW) is difficult due to their decay production and the formation of point defects. In essence, these will eventually destabilize the host crystalline oxides resulting in their amorphization and cracking.

Nuclear materials operate at extreme conditions. To host nuclear waste, numerous systems have been investigated using both experimental and computer simulation techniques [19]. The synergetic application of techniques leads to the more thorough fundamental understanding of the impact of radiation damage in materials and can lead to progress. An example is by Sickafus et al. [19], which determined that radiation tolerance in pyrochlore oxides $\left(\mathrm{A}_{2} \mathrm{~B}_{2} \mathrm{O}_{7}\right)$ is related to the ease with which that disorder can be accommodated. Previous work determined that oxides were defects that can readily form and are more resistant to radiation-induced amorphization and are thus important for the accommodation of radioactive waste [19].

Inspired by nanotechnology, there has been interest in annihilating defects and radiation damage through the use of nanocomposites. This is a new class of radiation tolerant materials with nanometres thick layers (i.e., maximization of interfaces) that can lead to very radiation resistant materials. An example is the studies of Demkowicz et al. [20] on the radiation damage resistance in $\mathrm{Cu}-\mathrm{Nb}$ multilayer nanocomposites (Figure 1). In this system, it was predicted using atomistic simulation that the interfaces in the nanocomposite effectively act as sinks for radiation-induced defects. As a word of caution, however, the application of finer grain wasteform materials will be a challenge due to the increased surface/area per unit volume that is thermodynamically less stable. This can be potentially problematic at the extended repository timescales.

In the recent work of Bai et al. [21], atomistic simulation was used to show that grain boundaries are not only sinks for radiation induced defects but can also emit interstitial atoms which can recombine with vacancies. This is considered to be important as it leads to concepts where grain boundaries will heal radiation-induced damage [21]. This is a breakthrough as the design principles relied on materials that could resist radiation damage, tolerate damage, or undergo lattice recovery. This is a further example of how nanotechnology can be used to produce designed grain-boundaries or interfacial structures to create advanced radiation tolerant materials. 

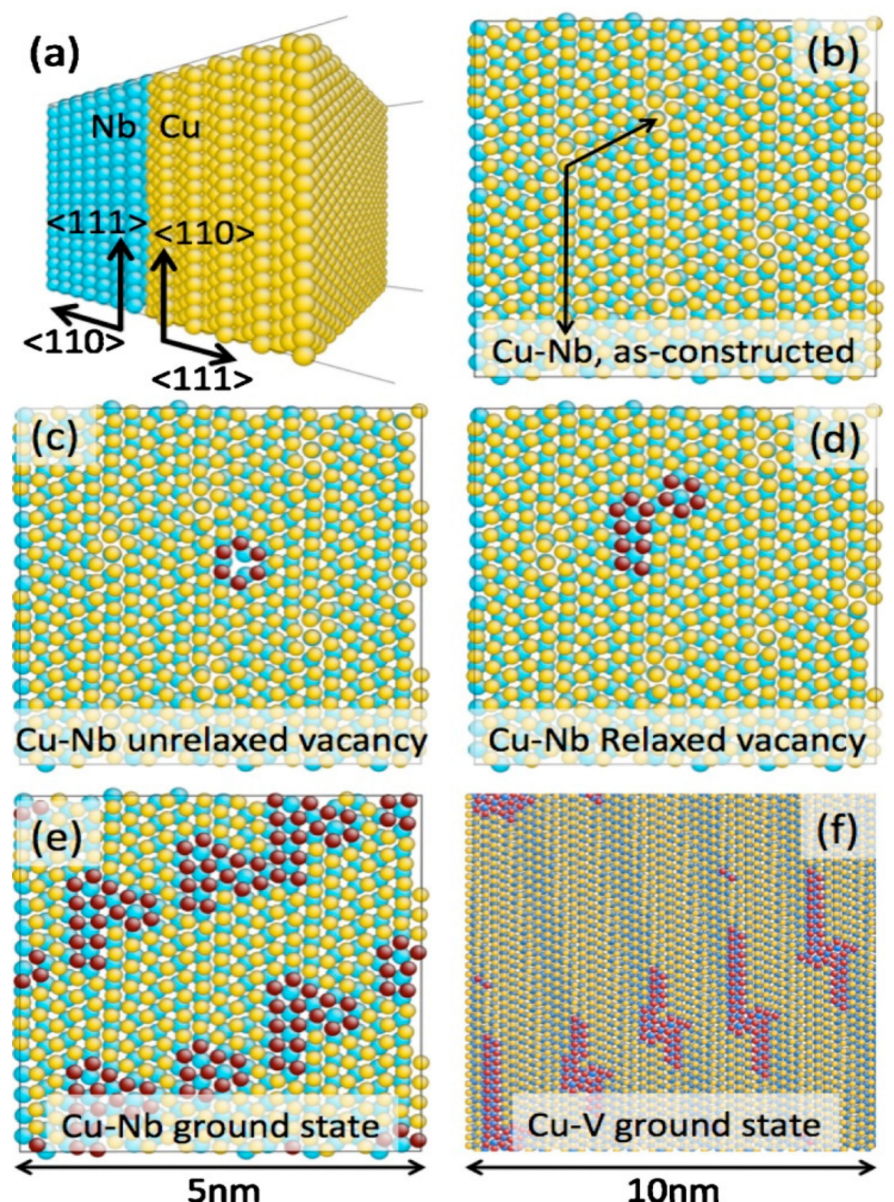

Figure 1. (a) Cu-Nb bilayer; (b) quasiperiodic pattern formed by the interface between $\mathrm{Cu}$ and $\mathrm{Nb}$ planes; (c) unrelaxed interface vacancy; (d) relaxed interface vacancy; (e) ground state $\mathrm{Cu}-\mathrm{Nb}$ interface with 5 at \% vacancies; (f) ground state $\mathrm{Cu}-\mathrm{V}$ interface with about 0.8 at \% vacancies. Dark red atoms that have less than six nearest neighbours in the interface $\mathrm{Cu}$ plane. Reproduced with permission from [20]. American Institute of Physics, 2010.

\section{Defect Engineering Oxygen Diffusion in Ceria}

\subsection{Motivation}

The importance of solid oxide fuel cells (SOFCs) lies in their potential for high efficiency energy conversion in conjunction with the reduced emission of greenhouse gases [22,23]. The high temperatures (up to $1000^{\circ} \mathrm{C}$ ) that SOFCs operate at to convert hydrogen and/or natural gas chemical energy to electricity can be detrimental for materials (for example thermal cycling and performance degradation), leading to increased cost [24,25]. Lowering the operating temperature (i.e., to $500-700{ }^{\circ} \mathrm{C}$ ) will be beneficial for material stability, however, it can also lead to increased losses for the reaction and transport kinetics in the cathode and electrolyte parts of the SOFC. A way to do this is to move away from traditional SOFC electrolyte materials such as yttria stabilised zirconia (YSZ) and towards materials such as rare-earth doped $\mathrm{CeO}_{2}$ that exhibit high oxygen self-diffusivities at these lower temperatures. Higher diffusivities are important for accelerating the oxygen transport in the electrolyte.

\subsection{Doping and Strain Strategies}

Oxygen self-diffusion in ceria is mediated by oxygen vacancies. Under equilibrium conditions the oxygen vacancy formation energy is high. A way to introduce oxygen vacancies to form an oxygen 
deficient structure is via doping with trivalent cations. Trivalent cations can substitute at cerium lattice sites with the defect equation in Kröger Vink notation being expressed as:

$$
\mathrm{X}_{2} \mathrm{O}_{3} \stackrel{\mathrm{CeO}_{2}}{\rightarrow} 2 \mathrm{X}_{\mathrm{Ce}}^{\prime}+\mathrm{V}_{\ddot{\mathrm{O}}}+3 \mathrm{O}_{\mathrm{O}}^{\mathrm{X}}
$$

Every oxygen vacancy is charge compensated by two trivalent ions that are introduced into the cation sublattice.

Trivalent doping in ceria is an efficient strategy leading to a SOFC electrolyte material with high oxygen ion diffusivity (for example, 2-3 orders of magnitude higher diffusivity as compared to yttria stabilized zirconia) in conjunction with relatively lower reduction temperatures [23]. In a previous molecular dynamics (MD) study [26], the activation energies of the oxygen migration of rare-earth doped ceria $\left(\mathrm{Ce}_{0.9} \mathrm{R}_{0.1} \mathrm{O}_{1.95}\right.$ where $\mathrm{R}=\mathrm{Yb}, \mathrm{Er}, \mathrm{Ho}, \mathrm{Dy}, \mathrm{Gd}, \mathrm{Sm}, \mathrm{Nd}$, and $\left.\mathrm{La}\right)$ as a function of the dopant ionic radius were considered (black line of Figure 2). The molecular dynamics calculations revealed that Nd-doped ceria had the lowest activation energy of oxygen migration (refer to Figure 2) [26]. This is reflected also in the oxygen diffusivities and therefore $\mathrm{Nd}$-doped ceria is appropriate for intermediate temperature $\left(500-700^{\circ} \mathrm{C}\right) \mathrm{SOFCs}$. It should be stressed, however, that at very high temperatures the energy barrier for oxygen diffusion is not significantly impacted by the association energy (Coulombic interactions and relaxation of the ceria lattice) of the dopant-oxygen vacancy clusters [26,27].

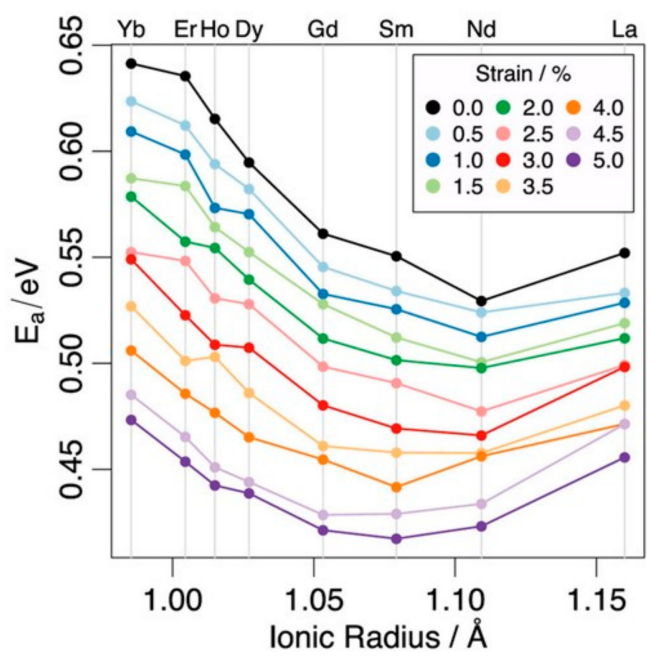

Figure 2. Molecular dynamics derived activation energies of oxygen migration with respect to the dopant ionic radius and uniaxial strain in $\mathrm{Ce}_{0.9} \mathrm{R}_{0.1} \mathrm{O}_{1.95}$ [26].

The community also imposes strain to increase oxygen diffusion and other physical properties in metal oxides [26,28]. From an experimental viewpoint, strain can be introduced by the formation of interfaces between dissimilar oxides and due to the complexity, atomistic simulation is commonly used to gain insights [29]. The advantage of computational modeling techniques is that they can be employed to deconvolute different contributions so that it becomes clear how strain impacts defect processes such as oxygen diffusion. This is essential in order to gain an understanding of the effect of strain and to be able to tune and optimize strain fields to achieve enhanced oxygen diffusion (Figure 3). Strain fields can be introduced (a) locally via doping with isovalent atoms or (b) by the formation of heterostructures resulting in epitaxial strain fields mainly near the interface between the layers of the dissimilar materials [30-32]. Interestingly, the work of Garcia-Barriocanal et al. [33] determined up to an eight order-of-magnitude increase in conductivity for epitaxially-grown zirconia/strontium titanate heterostructures and this motivated the community [26,34]. To clarify this unprecedented result, numerous atomistic simulation studies were employed given that in these it is easier to employ and control strain as compared to the experiment $[26,34]$. 


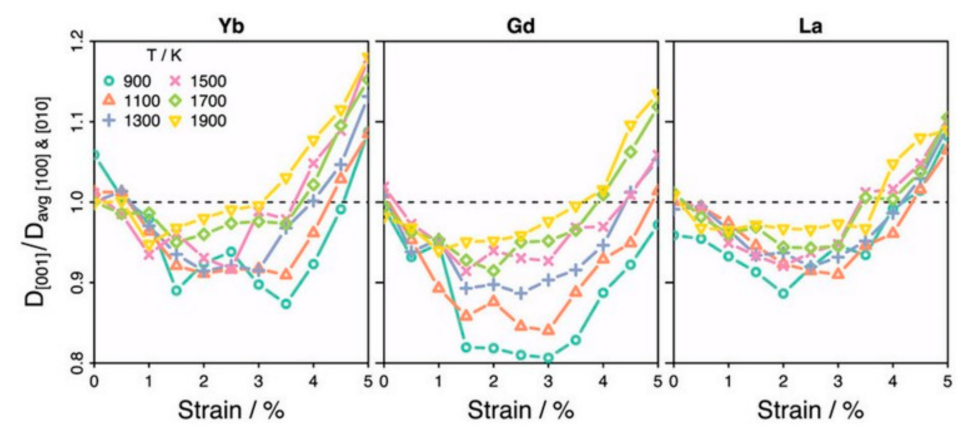

Figure 3. The influence of uniaxial strain, doping, and temperature on oxygen diffusivity in ceria [26].

At any rate, the accuracy of molecular dynamics simulations to describe oxygen diffusion in doped ceria will depend upon the potential model that should appropriately describe the thermal expansion of doped $\mathrm{CeO}_{2}$. For example, MD calculations were previously employed to study the effect of uniaxial strain on the oxygen ion diffusivity as a function of temperature and rare-earth dopant ( $\mathrm{Yb}, \mathrm{Er}, \mathrm{Ho}, \mathrm{Dy}, \mathrm{Gd}, \mathrm{Sm}, \mathrm{Nd}$ and La) using the well-established Cooper-Rushton-Grimes potential model that appropriately describes the thermal expansion of doped ceria [26]. This MD study is consistent with an increase of the oxygen diffusion coefficient due to strain, but not of the same order of magnitude as the study of Garcia-Barriocanal et al. [32] inferred. Given the flexibility of MD calculations to change conditions, it was shown that the increase in temperature will result in the decrease in the difference between the diffusivities between the dopants [26]. This in essence illustrates the diminishing impact of the association between the dopants and the oxygen vacancies [26]. Therefore, at temperatures above $1000 \mathrm{~K}$, the activation energy of oxygen migration will be primarily represented by the energy barrier required for diffusion, whereas the association energy of oxygen vacancy-dopant clusters will have a smaller contribution [35-37].

A very interesting feature that was demonstrated by the $\mathrm{MD}$ calculations for undoped $\mathrm{CeO}_{2}$ is that there is a limited increase of the oxygen diffusion coefficient for strains below $3 \%$ but there is a 15 -fold increase in the oxygen diffusion coefficient as the strain increased from $3.0 \%$ to $5.0 \%$ (refer to Figure 4) [26]. This in essence demonstrates that the strain not only impacts the association of dopants with the oxygen vacancies, but also leads to changes in the oxygen diffusivity because of the changes in the lattice.

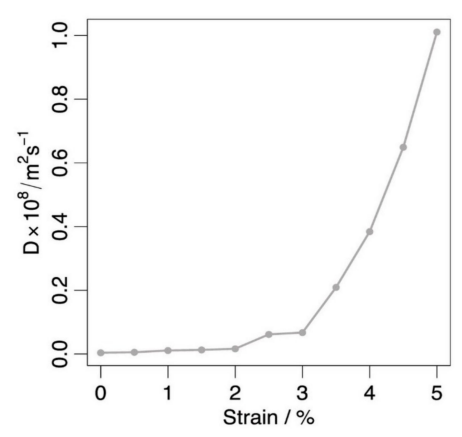

Figure 4. The molecular dynamics derived oxygen diffusivity with respect to uniaxial stain in undoped ceria [26].

\section{Doping Strategies in Silicon and Germanium}

\subsection{Isovalent Doping in Silicon}

For numerous years silicon has been the dominant electronic material in the semiconductor industry. This has been achieved by its beneficial material properties and the versatile silicon dioxide that allowed 
for the efficient miniaturization of microelectronic devices. Silicon dioxide has better properties and is more stable than germanium dioxide and this has allowed silicon to prevail over germanium at the dawn of the semiconductor industry, although the first transistor was made of germanium.

Isovalent doping in $\mathrm{Si}$ is technologically important (i.e., photovoltaics) and it can be used to improve the radiation hardness of Si [38]. In particular, it was previously determined that isovalent doping can suppress the formation of oxygen- and carbon-related radiation defects in $\mathrm{Si}$, thus allowing its application in photovoltaics [38]. The key is to immobilize vacancies as it is the key component of the vacancy-oxygen pair (VO or A-center) [39-41]. With the incorporation of large isovalent codopants in the silicon, elastic strains are induced around the defects due to the larger tetrahedral covalent radii of the dopants as compared to that of the host atom. These strains can be relieved by the attraction of a vacancy that in essence provides space for the lattice and the dopant to relax [38].

$\mathrm{Sn}$ is an isovalent dopant that is considerably larger than $\mathrm{Si}$, so it can strongly bind with vacancies and thus it can influence the vacancy-related defects and the generation rate of interstitial-related defects [42-45]. It was previously determined that $\mathrm{Sn}$ doping and in particular high concentration Sn doping will significantly impact the formation and diffusion of A-centers in $\mathrm{Si}$ (refer to Figure 5) [39-41,46]. The key is the formation of the highly bound SnVO clusters, which are far less mobile than VO [47]. Alongside $\mathrm{SnVO}$ clusters, $\mathrm{SnV}$ and $\mathrm{SnC}_{\mathrm{i}}$ defects may also form in irradiated $\mathrm{Si}$ [48]. The main purpose to introduce $\mathrm{Sn}$ atoms is to capture vacancies and consequently to improve the radiation hardness of $\mathrm{Si}$ in applications where this is required (for example, solar cells and detectors) [38]. This is because less vacancies will be unbound and available to form vacancy-related defects such as $\mathrm{VO}, \mathrm{VO}_{2}$, and $\mathrm{PV}$ (in $n$-type doped $\mathrm{Si}$ ), which will have a deleterious impact on the output and reliability of devices [38]. Sn doping can also influence the generation of oxygen thermal donors, and the aggregation and precipitation processes in Si. At any rate, however, the SnV defect induces electrical levels in the gap [49-51].

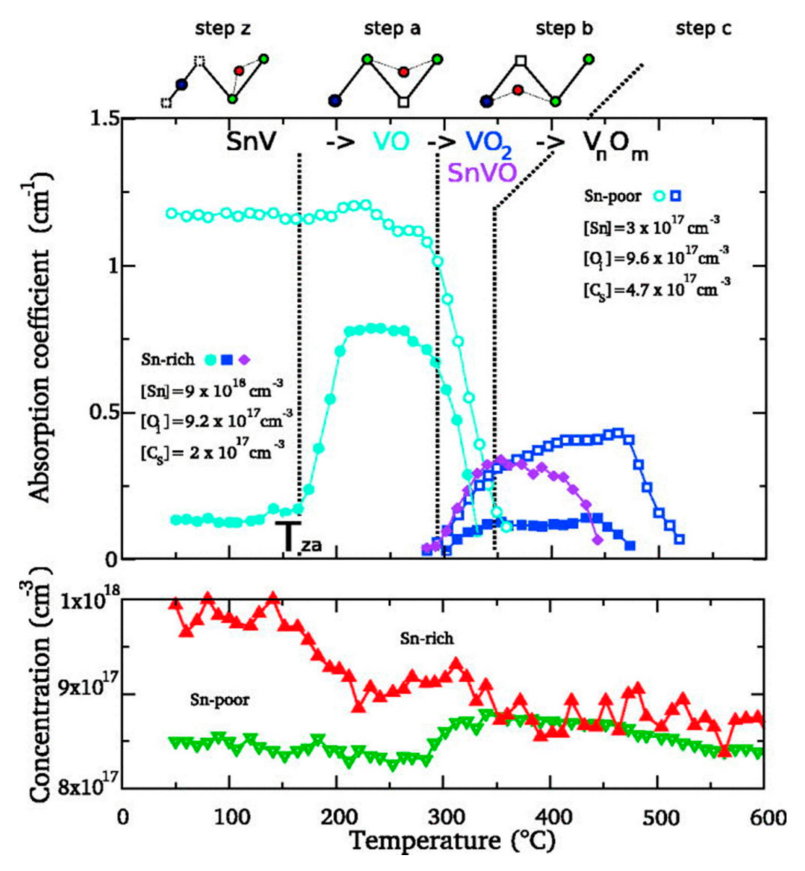

Figure 5. The thermal evolution of the $\mathrm{VO}$ (cyan circles), $\mathrm{VO}_{2}$ (dark blue squares), and SnVO (magenta diamonds) defects for poorly Sn-doped (open symbols) and highly Sn-doped (solid symbols) Si. The upper part is a schematic representation of the defects using blue and green circles for the Sn impurity and $\mathrm{Si}$ atoms, square and dotted squares for the $\mathrm{V}$ and semi-vacancy, and red circles for the oxygen interstitials. The bottom part is the thermal evolution of the oxygen interstitials for Sn-poor (open triangle) and Sn-rich (solid triangle) conditions. Reproduced with permission from [39]. American Institute of Physics, 2011. 


\subsection{Fluorine Doping in Germanium}

The introduction of alternative oxides in microelectronics and in particular high dielectric constant oxides (high- $k$ dielectrics such as hafnium oxide) has allowed the consideration of alternative substrates including germanium and III-V compounds [52-55]. Although Ge is isostructural to Si, its defect processes were considerably different and relatively neglected up until a decade ago [56-58]. The main issue that needs to be considered in Ge is the excessive $n$-type dopant diffusion, which can be significant as it is difficult to control so as to form appropriate $n$-type doped regions for devices.

A way to address this issue is via defect engineering strategies that can be employed to limit the harmful impact of defects, dopants, or their clusters in Ge (refer to Figure 6). A way to proceed is by the introduction of codopants or competing native defects at concentrations that will annihilate or control the defects, dopants, and their clusters. Bracht et al. [59] considered proton irradiation to form a supersaturation of Ge self-interstitials to annihilate the Ge vacancies. The formation of Ge interstitials is important as under equilibrium conditions, vacancies in Ge are the prevalent native point defects [3]. Vacancies mediate and are responsible for the fast diffusion of $n$-type dopants ( $\mathrm{P}, \mathrm{As}, \mathrm{or} \mathrm{Sb})$ and the formation of large dopant-vacancy clusters (refer to Figure 6) that lead to the deactivation of a large proportion of the dopants introduced and therefore need to be controlled [60-62].
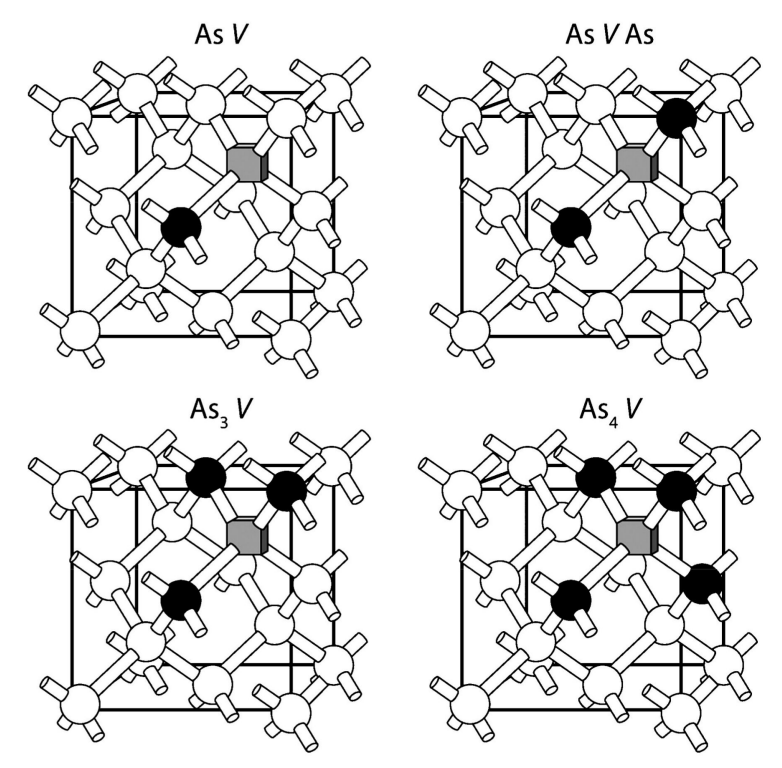

Figure 6. Schematic representation of the $\mathrm{As}_{\mathrm{n}} \mathrm{V}$ clusters in Ge. Cubes represent the vacancies, black circles represent the As atoms, and white circles represent the Ge atoms. Reproduced with permission from [8]. American Institute of Physics, 2007.

As in the case of $\mathrm{Si}$, a more straightforward path towards the control of the defect processes in Ge is through the incorporation of codopants. Previous experimental and theoretical studies considered codoping of $n$-type doped Ge with isovalent atoms such as $\mathrm{C}$ or Sn, aliovalent dopants such as fluorine, or a second $n$-type dopant (double donor doping) [3]. Density functional theory (DFT) and experimental studies consistently revealed that isovalent codoping and double donor doping in Ge do not effectively reduce the formation of dopant-vacancy clusters that can lead to deactivation [63,64]. The introduction of fluorine in Si and Ge is motivated as it is a dopant that can passivate the dangling bonds formed by the vacancies [65-70]. The key is the high electronegativity of $\mathrm{F}$ and via the saturation of the dangling bonds, and it essentially immobilizes the lattice vacancies. This is important as the vacancies are the key to control both the diffusion of donor atoms and the formation of the large donor atom-vacancy clusters that lead to the deactivation of the donor profile. In a DFT study which employed mass action analysis, it was shown that F will more effectively capture 
vacancies (forming $F_{n} V_{m}$ clusters) as compared to donor atoms and this will limit the concentration of the donor-vacancy clusters [68]. This theoretical study motivated Impellizzeri et al. [69] to investigate the effect of $\mathrm{F}$ on As diffusion in Ge. It was determined that $\mathrm{F}$ does reduce As diffusion in Ge (refer to Figure 7) [69]. Thereafter, the study of Jung et al. [70] was consistent and concluded that implanted $\mathrm{F}$ atoms can passivate the vacancies at around $500^{\circ} \mathrm{C}$ leading to an enhancement in Ge-metal-oxide semiconductor-field-effect transistor (MOSFET) performance [70]. In a recent study, Sanson et al. [71] investigated the local structure of $\mathrm{F}$ doped Ge by ion implantation and annealing using X-ray absorption near edge structure (XANES) spectroscopy. This study determined that most of the $\mathrm{F}$ in Ge forms $\mathrm{F}_{6} \mathrm{~V}_{2}$ complexes [71]. The excellent agreement of DFT and experiments to model F-doped Ge and the effectiveness of $F$ to capture vacancies to form $F_{n} V_{m}$ clusters demonstrates that their synergetic use leads to efficient defect engineering strategies that can accelerate the realization of advanced nanoelectronic devices [68-73].

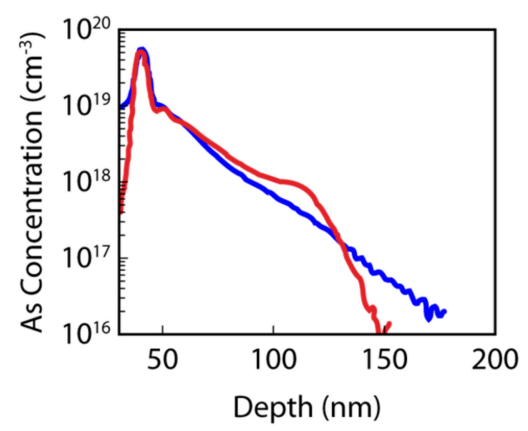

Figure 7. Arsenic concentration profiles with respect to depth for As-doped (blue line $3 \times 10^{13} \mathrm{As} / \mathrm{cm}^{2}$ with $50 \mathrm{keV}$ implantation energy) and $\mathrm{F}+$ As codoped (red line As: $3 \times 10^{13} \mathrm{As} / \mathrm{cm}^{2}$ with $50 \mathrm{keV}$ implantation energy; F: $1 \times 10^{15} \mathrm{~F} / \mathrm{cm}^{2}$ with $35 \mathrm{keV}$ implantation energy) Ge.

\section{Tuning Metal Oxides for Catalysis}

\subsection{Hydrogen Doping in $\mathrm{WO}_{3}$}

Tungsten oxide, $\mathrm{WO}_{3}$, can be used as a catalyst and catalyst support. To expand the range of applications to gas sensors and optoelectronics, it is necessary to control its intrinsic and/or extrinsic defect processes [74-82]. Importantly, although undoped and stoichiometric $\mathrm{WO}_{3}$ is insulating (band gap of 3-3.3 eV [76]), oxygen hypostoichiometric tungsten oxide has electrical conductivity and optical absorption (blue colour because of the gap narrowing) [78].

Hydrogen is an important dopant in metal oxides as it (a) can modify the band gap; (b) occupy interstitial sites with only limited distortion in the lattice; (c) induce insulator-to-conductor transitions; and (d) interact with intrinsic defects (for example, oxygen vacancies and interstitials) [76,79-82]. Understanding $\mathrm{H}$ doping and its impact in defect processes remains an active research area in many technologically important metal oxides including $\mathrm{WO}_{3}$ and $\mathrm{TiO}_{2}$.

Considering $\mathrm{WO}_{3}$, Zhu et al. [76] used DFT calculations to study the structure and formation of defects. Figure 8 represents the configurations of defects in $\mathrm{WO}_{3}$ reported in the study of Zhu et al. [76]. The calculations show that the $\mathrm{O}$ atoms that surround a $\mathrm{W}$ vacancy $\left(\mathrm{V}_{\mathrm{W}}\right)$ have only small distortions from their original positions, conversely to surrounding $\mathrm{W}$ atoms towards an $\mathrm{O}$ vacancy $\left(\mathrm{V}_{\mathrm{O}}\right)$ which exhibit significant distortions [76]. In $\mathrm{WO}_{3}$, the oxygen interstitials form at the body center $\left(\mathrm{O}_{\mathrm{i}}-1\right)$ or at the vicinity of a $\mathrm{W}$ atom $\left(\mathrm{O}_{\mathrm{i}}-2\right)$-refer to Figure 8 [76]. The $\mathrm{W}$ interstitial $\left(\mathrm{W}_{\mathrm{i}}\right)$ atom is stable at the body center having a larger bond length (W-O bond length of $2.08 \AA$ ) as compared to the perfect structure bond length (1.93 $\AA$ ) [76]. Figure 8 represents the three possibilities for $\mathrm{H}_{\mathrm{i}}$ : (a) bond to a single $\mathrm{O}$ atom (O-H distance of $\left.0.98 \AA, \mathrm{H}_{\mathrm{i}}-1\right)$; (b) be located at the face center (O-H distances of $1.01 \AA$ and $1.67 \AA$, $\left.\mathrm{H}_{\mathrm{i}}-2\right)$; and (c) form the $(\mathrm{HO})_{\mathrm{i}}$ interstitial defect (O-H distances of $1.02 \AA$ and $1.50 \AA$ ) [76]. 


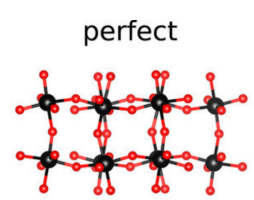

$\mathrm{W}_{\mathrm{i}}$

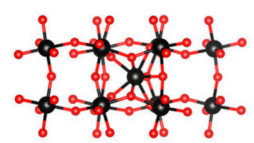

$\mathrm{H}_{\mathrm{i}}-1$

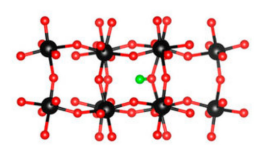

$\mathrm{V}_{\mathrm{W}}$

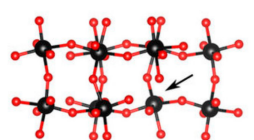

$\mathrm{O}_{\mathrm{i}-1}$

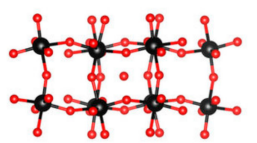

$\mathrm{H}_{\mathrm{i}}-2$

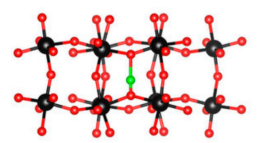

$\mathrm{V}_{\mathrm{O}}$

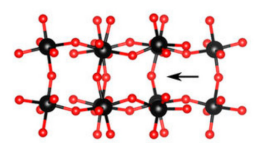

$\mathrm{O}_{\mathrm{i}-2}-2$

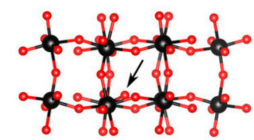

$(\mathrm{HO})_{\mathrm{i}}$

Figure 8. Configurations of defects in $\mathrm{WO}_{3}$ considered using density functional theory by Zhu et al. [76]. W, O, and $\mathrm{H}$ atoms are represented by black, red, and green spheres, respectively.

Figure 9 reports the formation energies of intrinsic and $\mathrm{H}$-related defects in $\mathrm{WO}_{3}$ with respect to the Fermi level (O-rich and O-poor limits) for a range of charge states [76]. It can be observed that at the O-poor limit, the formation energy of $\mathrm{V}_{\mathrm{O}}$ is much lower as compared to $\mathrm{V}_{\mathrm{W}}$ and even negative for most of the values of the Fermi level (refer to Figure 8) [76]. For the O-rich limit, when the Fermi level is high, $V_{W}$ becomes more energetically favourable compared to $V_{O}$ [76]. For the oxygen interstitial defects, the formation energy of $\mathrm{O}_{\mathrm{i}}-1$ is higher than that of $\mathrm{O}_{\mathrm{i}}-2$ (refer to Figure 8 for the configurations and Figure 9 for the formation energies) and this is because the $\mathrm{O}_{\mathrm{i}}-1$ does not form chemical bonds [76]. Both oxygen interstitials have positive formation energies. Conversely, the $\mathrm{W}_{\mathrm{i}}$ defect (+6 charge state) has a negative formation energy in the O-poor limit (refer to Figure 9) [76]. Interestingly, the $W_{i}$ formation energy is higher compared to the oxygen interstitials for O-rich conditions and when the Fermi level exceeds the middle of the band gap $\mathrm{W}_{\mathrm{i}}$ (refer to Figure 9) [76].

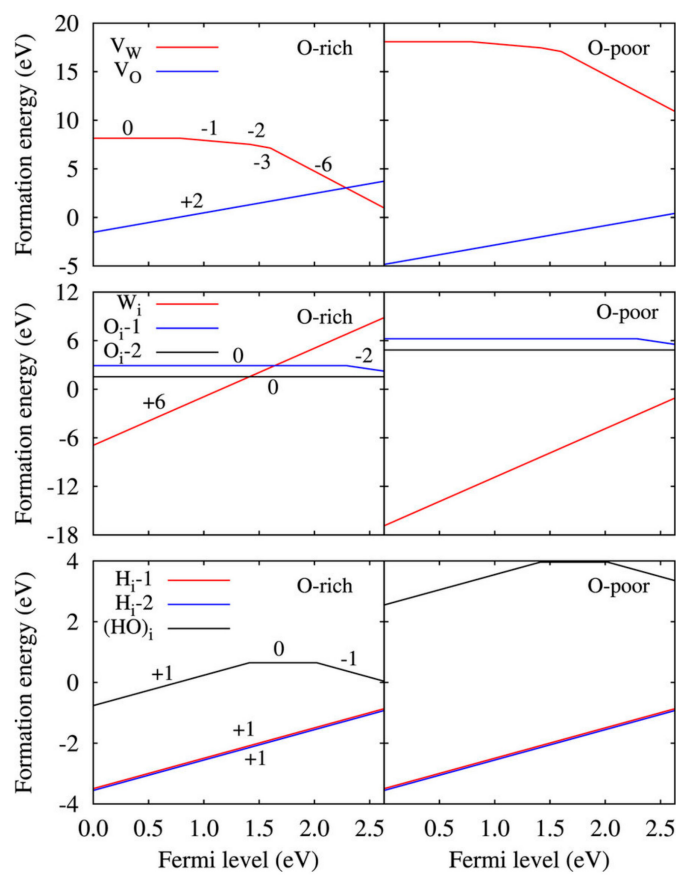

Figure 9. Formation energies of intrinsic and $\mathrm{H}$-related defects in $\mathrm{WO}_{3}$ with respect to the Fermi level (O-rich and O-poor limits) for a range of charge states [76]. 
Considering hydrogen which is an extrinsic defect in $\mathrm{WO}_{3}$, it is calculated that hydrogen interstitial defects $\left(\mathrm{H}_{\mathrm{i}}-1\right.$ and $\left.\mathrm{H}_{\mathrm{i}}-2\right)$ have negative formation energies and are therefore readily incorporated to form $\mathrm{H}_{\mathrm{z}} \mathrm{WO}_{3-x}$ (refer to Figures 8 and 9) [76]. Additionally, the formation of other H-related defects is predicted to be possible such as the $(\mathrm{HO})_{\mathrm{i}}$ defect under O-rich conditions (refer to Figures 8 and 9) [76].

Although perfect $\mathrm{WO}_{3}$ has a direct band gap ( $2.56 \mathrm{eV}$ to $3.2 \mathrm{eV}$ ) in the presence of $\mathrm{V}_{\mathrm{w}}$ and $\mathrm{O}_{\mathrm{i}}-2$, the band gap becomes indirect and reduced by the in-gap states (to $0.70 \mathrm{eV}$ for $\mathrm{V}_{\mathrm{w}}$ and $2.23 \mathrm{eV}$ for $\left.\mathrm{O}_{\mathrm{i}}-2\right)[76,81,82]$. The introduction of $\mathrm{V}_{\mathrm{O}}, \mathrm{W}_{\mathrm{i}}$, and $\mathrm{H}_{\mathrm{i}}-2$ defects will lead to a metallic character [76]. Therefore, the control of the intrinsic and extrinsic defect is important to tune the electronic properties of $\mathrm{WO}_{3}$ in view of its applications.

\subsection{Codoping in $\mathrm{TiO}_{2}$}

Ever since the seminal study of Fujishima and Honda [83], titanium oxide $\left(\mathrm{TiO}_{2}\right)$ has been intensively investigated because of its high chemical stability, strong catalytic activity, and long lifetime of photon generated carriers [83-91]. Anatase is the polymorph of $\mathrm{TiO}_{2}$ with the highest photocatalytic activity, but has a large band gap $(3.2 \mathrm{eV})$ and this limits its use in the limited ultraviolet range which is only $5 \%$ of the solar spectrum [89]. Ideally a photocatalyst should have a band gap of $\sim 2 \mathrm{eV}$, whereas band edges must be consistent with the redox potential of water [92].

Gai et al. [89] proposed that the band edges of $\mathrm{TiO}_{2}$ can be modified by codoping aiming to shift the valence band edge up, while retaining the conduction band edge. Gai et al. [89] considered a number of codopants such as $\mathrm{V}+\mathrm{N}, \mathrm{Nb}+\mathrm{N}, \mathrm{Cr}+\mathrm{C}$ and $\mathrm{Mo}+\mathrm{C}$ (refer to Figure 10). The DFT results indicate that $\mathrm{Mo}+\mathrm{C}$ codoped $\mathrm{TiO}_{2}$ is a strong candidate for photo-electro-catalytic (PEC) hydrogen production via water splitting, as it reduces the band gap to the visible light region and without practically impacting the conduction band minimum [89]. The study by Gai et al. [89] has significantly impacted the community to determine appropriate codoping strategies to improve anatase and related materials [93-97].

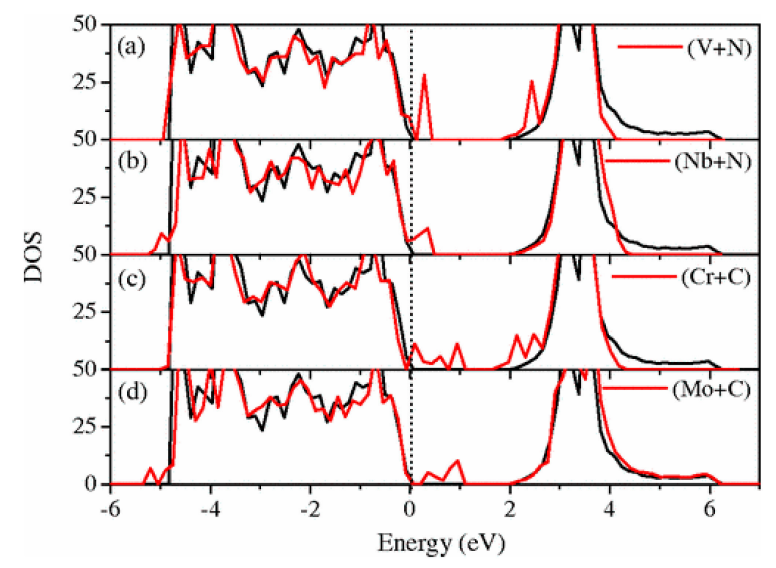

Figure 10. Density of states results of undoped $\mathrm{TiO}_{2}$ and codoped- $\mathrm{TiO}_{2}$. Reproduced with permission from [89]. American Physical Society, 2009.

An efficient way to achieve the reduction of the band gap is via nitrogen $(\mathrm{N})$ doping $[85,98]$. As in the case of $\mathrm{WO}_{3}$ considered above, $\mathrm{H}$ is introduced in $\mathrm{TiO}_{2}$ to modify the band gap and enhance the photocatalytic activity $[79,80,99,100]$. Hydrogen can be easily incorporated in $\mathrm{TiO}_{2}$ during synthesis or by simply immersing it in water [98]. Importantly, previous theoretical studies by Van de Walle et al. [101,102] showed that hydrogen substitutionals at oxygen sites lead to $n$-type conductivity. Codoping anatase with $\mathrm{N}$ and $\mathrm{H}$ has been considered by the community as an effective defect engineering strategy to reduce the band gap, increase the conductivity, and passivate surface dangling bonds aimed at forming high-efficiency devices (for example, organic photovoltaics [90]). 
Other dopants and codopants (such as fluorine) have also been employed, whereas simple methods such as vacuum annealing can also form oxygen vacancies and increase the activity.

\section{Summary and Future Outlook}

Considerable research is focused on the use of nuclear energy as a key component in the future energy mix as its use can lead to reduced $\mathrm{CO}_{2}$ emissions. Future nuclear reactors will need to be safer, more efficient, more economic, and proliferation resistant. Consequently, there are numerous materials science and engineering challenges that will need to be addressed. One key factor is the safe deposition of nuclear waste, as it may influence public support of the newly built reactors. In that respect, new radiation tolerant materials are required and defect engineering strategies can be used to design advanced nuclear materials.

MD studies in agreement with experiments support the viewpoint that strain significantly impacts the oxygen diffusion coefficient and activation energy for migration in ceria. This effect can be traced to the changes in the binding energies between the vacancy and the rare-earth dopant [26]. Atomistic simulation can deconvolute the impact of the different contributions to the energetics of self-diffusion and for ceria the MD calculations revealed that there is an effect of strain even in undoped ceria and this in turn implies a more fundamental relationship between strain and diffusion energetics that should be investigated [26].

The third example considered defect engineering strategies in two important semiconductor materials; $\mathrm{Si}$ and Ge. In these systems, it was demonstrated that DFT in synergy with experiments can lead to effective ways to contain vacancy-related defects (A-centers in Si and E-centers in Ge). It was shown that even relatively simple DFT calculations can lead to insights and to methods to limit the concentration of vacancies, thus limiting the formation of A-centers in $\mathrm{Si}$ and constraining the diffusion of $n$-type dopants in Ge.

In metal oxides, the aim was to demonstrate that codoping with $\mathrm{H}$ and/or $\mathrm{N}$ can lead to the improvement of their properties so that they can be implemented in a wide range of applications, such as organic photovoltaics, gas sensors, and optoelectronics. Using DFT it was demonstrated that intrinsic defects and doping can be used to tune the electronic properties of metal oxide, such as anatase and tungsten oxide. For example, the introduction of nitrogen can effectively reduce the band gap of anatase, improving its photocatalytic activity. The band-edge modification via codoping is expected to be a defect engineering strategy that can be transferable to other wide-band-gap semiconductors.

Finally, it should be considered that experimental and computational techniques can be used in conjunction with established thermodynamic models, such as the $\mathrm{cB} \Omega$ model by Varotsos and Alexopoulos, to study defect processes to design advanced energy and electronic materials [103-111]. In the $c B \Omega$ model, the defect Gibbs energy is assumed to be proportional to the isothermal bulk modulus (B) and the mean volume per atom $(\Omega)$. Recent advances in computational materials science and experimental techniques have regenerated the interest in its use to predict defect processes under extreme conditions [110-119].

Acknowledgments: Alexander Chroneos is grateful for funding from the Lloyd's Register Foundation, a charitable foundation helping to protect life and property by supporting engineering-related education, public engagement, and the application of research.

Author Contributions: The manuscript was written and edited by all of the authors.

Conflicts of Interest: The authors declare no conflict of interest.

\section{References}

1. Seymour, I.D.; Chroneos, A.; Kilner, J.A.; Grimes, R.W. Defect processes in orthorhombic $\mathrm{LnBaCo}_{2} \mathrm{O}_{5.5}$ double perovskites. Phys. Chem. Chem. Phys. 2011, 13, 15305-15310. [CrossRef] [PubMed]

2. Murphy, S.T.; Chroneos, A.; Jiang, C.; Schwingenschlögl, U.; Grimes, R.W. Deviations from Vegard's law in ternary III-V alloys. Phys. Rev. B 2010, 82, 073201. [CrossRef] 
3. Chroneos, A.; Bracht, H. Diffusion of n-type dopants in germanium. Appl. Phys. Rev. 2014, 1, 011301. [CrossRef]

4. Horlait, D.; Middleburgh, S.C.; Chroneos, A.; Lee, W.E. Synthesis and DFT investigation of new bismuth-containing MAX phases. Sci. Rep. 2016, 6, 18829. [CrossRef] [PubMed]

5. Solovjov, A.L.; Tkachenko, M.A.; Vovk, R.V.; Chroneos, A. Fluctuation conductivity and pseudogap in $\mathrm{HoBa}_{2} \mathrm{Cu}_{3} \mathrm{O}_{7-\delta}$ single crystals under pressure with transport current flowing under an angle $45^{\circ}$ to the twin boundaries. Phys. C Supercond. 2014, 501, 24-31. [CrossRef]

6. Horlait, D.; Grasso, S.; Chroneos, A.; Lee, W.E. Attempts to synthesise quaternary MAX phases $(\mathrm{Zr}, \mathrm{M})_{2} \mathrm{AlC}$ and $\mathrm{Zr}_{2}(\mathrm{Al}, \mathrm{A}) \mathrm{C}$ as a way to approach $\mathrm{Zr}_{2} \mathrm{AlC}$. Mater. Res. Lett. 2016, 4, 137-144. [CrossRef]

7. Zapata-Solvas, E.; Christopoulos, S.R.G.; Ni, N.; Parfitt, D.C.; Horlait, D.; Fitzpatrick, M.E.; Chroneos, A.; Lee, W.E. Experimental synthesis and density functional theory investigation of radiation tolerance of $\mathrm{Zr}_{3}\left(\mathrm{Al}_{1-x} \mathrm{Si}_{x}\right) \mathrm{C}_{2}$ MAX phases. J. Am. Ceram. Soc. 2017, 100, 1377-1387. [CrossRef]

8. Chroneos, A.; Grimes, R.W.; Uberuaga, B.P.; Brotzmann, S.; Bracht, H. Vacancy-arsenic clusters in germanium. Appl. Phys. Lett. 2007, 91, 192106. [CrossRef]

9. Vovk, R.V.; Obolenskii, M.A.; Zavgorodniy, A.A.; Goulatis, I.L.; Beleskii, V.I.; Chroneos, A. Structural relaxation, metal to insulator transition and pseudo-gap in oxygen deficient $\mathrm{HoBa}_{2} \mathrm{Cu}_{3} \mathrm{O}_{7-\delta}$ single crystals. Phys. C Supercond. 2009, 469, 203-206. [CrossRef]

10. Vovk, R.V.; Vovk, N.R.; Shekhovtsov, O.V.; Goulatis, I.L.; Chroneos, A. c-axis hopping conductivity in heavily Pr-doped YBCO single crystals. Supercond. Sci. Technol. 2013, 26, 085017. [CrossRef]

11. Jacobson, M.Z. Review of solutions to global warming, air pollution, and energy security. Energy Environ. Sci. 2009, 2, 148-173. [CrossRef]

12. Devanathan, R.; Weber, W.J.; Gale, G.D. Radiation tolerance of ceramics- insights from atomistic simulation of damage accumulation in pyrochlores. Energy Environ. Sci. 2010, 3, 1551-1559. [CrossRef]

13. Grimes, R.W.; Nuttal, W.J. Generating the option of a two-stage nuclear renaissance. Science 2010, 329, 799-803. [CrossRef] [PubMed]

14. Degueldre, C.; Bertsch, J.; Kuri, G.; Martin, M. Nuclear fuel in generation II and III reactors: Research issues related to high burn-up. Energy Environ. Sci. 2011, 4, 1651-1661. [CrossRef]

15. Armaroli, N.; Balzani, V. Towarss an electricity-powered world. Energy Environ. Sci. 2011, 4, 3193-3222.

16. Grimes, R.W.; Konings, R.J.M.; Edwards, L. Greater tolerance for nuclear materials. Nat. Mater. 2008, 7, 683-685. [CrossRef] [PubMed]

17. Ewing, R.C. Nuclear waste forms for actinides. Proc. Natl. Acad. Sci. USA 1999, 96, 3432-3439. [CrossRef] [PubMed]

18. Winograd, I.J.; Roseboom, E.H., Jr. Yucca mountain revisited. Science 2008, 320, 1426-1427. [CrossRef] [PubMed]

19. Sickafus, K.E.; Minervini, L.; Grimes, R.W.; Valdez, J.A.; Ishimaru, M.; Li, F.; McClellan, K.J.; Hartmann, T. Radiation tolerance of complex oxides. Science 2000, 289, 748-751. [CrossRef] [PubMed]

20. Demkowicz, M.J.; Bhattacharyya, D.; Usov, I.; Wang, Y.Q.; Nastasi, M.; Misra, A. The effect of excess atomic volume on He bubble formation at fcc-bcc interfaces. Appl. Phys. Lett. 2010, 97, 161903. [CrossRef]

21. Bai, X.M.; Voter, A.F.; Hoagland, R.G.; Nastasi, M.; Uberuaga, B.P. Efficient annealing of radiation damage near grain boundaries via interstitial emission. Science 2010, 327, 1631-1634. [CrossRef] [PubMed]

22. Singhal, S.C. Advances in solid oxide fuel cell technology. Solid State Ionics 2000, 135, 305-313. [CrossRef]

23. Steele, B.C.H.; Heinzel, A. Materials for fuel-cell technologies. Nature 2001, 414, 345-352. [CrossRef] [PubMed]

24. Minh, N.Q.; Takahashi, T. Science and Technology of Ceramic Fuel Cells; Elsevier: Amsterdam, The Netherlands, 1995.

25. Jacobson, A.J. Materials for solid oxide fuel cells. Chem. Mater. 2010, 22, 660-674. [CrossRef]

26. Rushton, M.J.D.; Chroneos, A. Impact of uniaxial strain and doping on oxygen diffusion in $\mathrm{CeO}_{2}$. Sci. Rep . 2014, 4, 6068. [CrossRef] [PubMed]

27. Steele, B.C.H. Appraisal of $\mathrm{Ce}_{1-y} \mathrm{Gd}_{y} \mathrm{O}_{2-y / 2}$ electrolytes for IT-SOFC operation at $500{ }^{\circ} \mathrm{C}$. Solid State Ionics 2000, 129, 95-110. [CrossRef]

28. Sata, N.; Eberman, K.; Eberl, K.; Maier, J. Mesoscopic fast ion conduction in nanometre scale planar heterostructures. Nature 2000, 408, 946-949. [CrossRef] [PubMed] 
29. Kushima, A.; Yildiz, B. Oxygen ion diffusivity in strained yttria stabilized zirconia: Where is the fastest strain? J. Mater. Chem. 2010, 20, 4809-4819. [CrossRef]

30. Guo, X.X.; Matei, I.; Lee, J.-S.; Maier, J. Ion conduction across nanosized $\mathrm{CaF}_{2} / \mathrm{BaF}_{2}$ multilayer heterostructures. Appl. Phys. Lett. 2007, 91, 103102. [CrossRef]

31. Kilner, J.A. Ionic conductors feel the strain. Nat. Mater. 2008, 7, 838-839. [CrossRef] [PubMed]

32. Shen, W.; Jiang, J.; Hertz, J.L. Reduced ionic conductivity in biaxially compressed ceria. RSC Adv. 2014, 4, 21625-21630. [CrossRef]

33. Garcia-Barriocanal, J.; Rivera-Calzada, A.; Varela, M.; Sefrioui, Z.; Iborra, E.; Leon, C.; Pennycook, S.J.; Santamaria, J. Colossal ionic conductivity at interfaces of epitaxial $\mathrm{ZrO}_{2}: \mathrm{Y}_{2} \mathrm{O}_{3} / \mathrm{SrTiO}_{3}$ heterostructures. Science 2008, 321, 676-680. [CrossRef] [PubMed]

34. De Souza, R.A.; Ramadan, A.; Hörner, S. Modifying the barriers for oxygen vacancy migration in fluorite structured $\mathrm{CeO}_{2}$ electrolytes through strain: A computer simulation study. Energy Environ. Sci. 2011, 5, 5445-5453. [CrossRef]

35. Kilner, J.A.; Waters, C.D. The effects of dopant cation oxygen vacancy complexes on the anion transport properties of nonstoichiometric fluorite oxides. Solid State Ionics 1982, 6, 253-259. [CrossRef]

36. Minervini, L.; Zacate, M.O.; Grimes, R.W. Defect cluster formation in $\mathrm{M}_{2} \mathrm{O}_{3}$ doped $\mathrm{CeO}_{2}$. Solid State Ionics 1999, 116, 339-349. [CrossRef]

37. Rushton, M.J.D.; Chroneos, A.; Skinner, S.J.; Kilner, J.A.; Grimes, R.W. Effect of strain on the oxygen diffusion in yttria and gadolinia co-doped ceria. Solid State Ionics 2013, 230, 37-42. [CrossRef]

38. Chroneos, A.; Sgourou, E.N.; Londos, C.A.; Schwingenschlögl, U. Oxygen defect processes in silicon and silicon germanium. Appl. Phys. Rev. 2015, 2, 021306. [CrossRef]

39. Chroneos, A.; Londos, C.A.; Sgourou, E.N.; Pochet, P. Point defect engineering strategies to supress A-center formation in silicon. Appl. Phys. Lett. 2011, 99, 241901. [CrossRef]

40. Chroneos, A.; Londos, C.A.; Sgourou, E.N. Effect of tin doping on oxygen and carbon related defects in Czochralski silicon. J. Appl. Phys. 2011, 110, 093507. [CrossRef]

41. Sgourou, E.N.; Timerkaeva, D.; Londos, C.A.; Aliprantis, D.; Chroneos, A.; Caliste, D.; Pochet, P. Impact of isovalent doping on the trapping of vacancy and interstitial related defects in Si. J. Appl. Phys. 2013, 113, 113506. [CrossRef]

42. Simoen, E.; Clays, C.; Neimash, V.; Kraitchinskii, A.; Kras'ko, N.; Puzenko, O.; Blondeel, A.; Clauws, P. Deep levels in high energy proton irradiated tin-doped n-type Czochralski silicon. Appl. Phys. Lett. 2000, 76, 2838. [CrossRef]

43. Khirunenko, L.I.; Kobzar, O.A.; Pomozov, Y.V.; Shakhovstov, V.I.; Sosnin, M.G.; Tripachko, N.A.; Markevich, V.P.; Murin, L.I.; Peaker, A.R. Defect-impurity interactions in irradiated tin-doped Cz-Si crystals. Phys. Status Solidi C 2003, 0, 694-697. [CrossRef]

44. Larsen, A.N.; Goubet, J.J.; Mejlholm, P.; Christensen, J.S.; Fanciulli, M.; Gunnlaugsson, H.P.; Weyer, P.; Petersen, J.W.; Resende, A.; Kaukonen, N.; et al. Tin-vacancy acceptor levels in electron irradiated $n$-type silicon. Phys. Rev. B 2000, 62, 4535-4544. [CrossRef]

45. Lavrov, E.V.; Fancialli, M.; Kaukonen, M.; Jones, R.; Briddon, P.R. Carbon-tin defects in silicon. Phys. Rev. B 2001, 64, 125212. [CrossRef]

46. Londos, C.A.; Aliprantis, D.; Sgourou, E.N.; Chroneos, A.; Pochet, P. Formation and evolution of oxygen-vacancy clusters in lead and tin doped silicon. J. Appl. Phys. 2012, 111, 123508. [CrossRef]

47. Wang, H.; Chroneos, A.; Londos, C.A.; Sgourou, E.N.; Schwingenschlögl, U. Doping strategies to control A-centres in silicon: Insights from hybrid density functional theory. Phys. Chem. Chem. Phys. 2014, 16, 8487-8492. [CrossRef] [PubMed]

48. David, M.L.; Simoen, E.; Clays, C.; Neimash, V.; Kras'ko, N.; Kraitchinskii, A.; Voytovych, V.; Kabaldin, A.; Barbot, J.F. Electrically active defects in irradiated $n$-type Czochralski silicon doped with group IV impurities. J. Phys. Condens. Matter 2005, 17, S2255. [CrossRef]

49. Fanciulli, M.; Byberg, J.R. Tin-vacancy complexes in e irradiated n-type silicon. Phys. Rev. B 1999, 273-274, 524-527. [CrossRef]

50. Simoen, E.; Clays, C.; Privitera, V.; Coffa, S.; Larsen, A.N.; Clauws, P. High energy proton radiation induced defects in tin doped $n$-type silicon. Phys. Rev. B 2001, 308-310, 477-480. [CrossRef]

51. Ghao, C.; Ma, X.; Zhao, J.; Yang, D. Effect of tin on point defects and oxygen precipitation on Czochralski silicon: Experimental and theoretical studies. J. Appl. Phys. 2013, 113, 093511. [CrossRef] 
52. Heyns, M.; Tsai, W. Ultimate scaling of CMOS logic devices with Ge and III-V materials. MRS Bull. 2009, 34, 485-492.

53. Tsoutsou, D.; Panayiotatos, Y.; Sotiropoulos, A.; Mavrou, G.; Golias, E.; Galata, S.F.; Dimoulas, A. Chemical stability of lanthanum germanate passivating layer on Ge upon high- $k$ deposition: A photoemission study on the role of La in the interface chemistry. J. Appl. Phys. 2010, 108, 064115. [CrossRef]

54. Chroneos, A.; Schwingenschlögl, U.; Dimoulas, A. Impurity diffusion, point defect engineering and surface/interface passivation in germanium. Ann. Phys. 2012, 524, 123-132. [CrossRef]

55. Galata, S.F.; Evangelou, E.K.; Panayiotatos, Y.; Sotiropoulos, A.; Dimoulas, A. Post deposition annealing studies of lanthanum aluminate and ceria high- $k$ dielectrics on germanium. Microelectron. Reliab. 2007, 47, 532-535. [CrossRef]

56. Chen, D.K.; Schrimpf, R.D.; Fleetwood, D.M.; Galloway, K.F.; Pantelides, S.T.; Dimoulas, A.; Mavrou, G.; Sotiropoulos, A.; Panayiotatos, Y. Total dose response of Ge MOS capasitors with $\mathrm{HfO}_{2} / \mathrm{Dy}_{2} \mathrm{O}_{3}$ gate stacks. IEEE Trans. Nucl. Sci. 2007, 54, 971-974. [CrossRef]

57. Chroneos, A.; Skarlatos, D.; Tsamis, C.; Christofi, A.; McPhail, D.S.; Hung, R. Implantation an diffusion of phosphorous in germanium. Mater. Sci. Semicond. Process 2006, 9, 640-643. [CrossRef]

58. Chroneos, A. Dopant-vacancy cluster formation in germanium. J. Appl. Phys. 2010, 107, 076102. [CrossRef]

59. Bracht, H.; Schneider, S.; Klug, J.N.; Liao, C.J.; Lundsgaard Hansen, J.; Haller, E.E.; Nylandsted Larsen, A.; Bougeard, D.; Posselt, M.; Wündisch, C. Interstitial-mediated diffusion in germanium under proton irradiation. Phys. Rev. Lett. 2009, 103, 255501. [CrossRef] [PubMed]

60. Brotzmann, S.; Bracht, H. Intrinsic and extrinsic diffusion of phosphorous, arsenic, and antimony in germanium. J. Appl. Phys. 2008, 103, 033508. [CrossRef]

61. Chroneos, A.; Bracht, H.; Grimes, R.W.; Uberuaga, B.P. Vacancy-mediated dopant diffusion activation enthalpies for germanium. Appl. Phys. Lett. 2008, 92, 172103. [CrossRef]

62. Tsouroutas, P.; Tsoukalas, D.; Bracht, H. Experiments and simulation on diffusion and activation of codoped with arsenic and phosphorous germanium. J. Appl. Phys. 2010, 108, 024903. [CrossRef]

63. Brotzmann, S.; Bracht, H.; Lundsgaard Hansen, J.; Nylandsted Larsen, A.; Simoen, E.; Haller, E.E.; Christensen, J.S.; Werner, P. Diffusion and defect reactions between donors, C, and vacancies in Ge. I Experimental results. Phys. Rev. B 2008, 77, 235207. [CrossRef]

64. Chroneos, A.; Grimes, R.W.; Uberuaga, B.P.; Bracht, H. Diffusion and defect reactions between donors, C, and vacancies in Ge. II Atomistic calculations of related complexes. Phys. Rev. B 2008, 77, 235208. [CrossRef]

65. Diebel, M.; Dunham, S.T. Ab initio calculations to model anomalous fluorine behavior. Phys. Rev. Lett. 2004, 93, 245901. [CrossRef] [PubMed]

66. Bernardi, F.; dos Santos, J.H.R.; Behar, M. Lattice site investigation of F in preamorphized Si. Phys. Rev. B 2007, 76, 033201. [CrossRef]

67. Boninelli, S.; Impellizzeri, G.; Mirabella, S.; Priolo, F.; Napolitani, E.; Cherkashin, N.; Cristiano, F. Formation and evolution of F nanobubbles in amorphous and crystalline Si. Appl. Phys. Lett. 2008, 93, 061906. [CrossRef]

68. Chroneos, A.; Grimes, R.W.; Bracht, H. Fluorine codoping in germanium to suppress donor diffusion and deactivation. J. Appl. Phys. 2009, 106, 063707. [CrossRef]

69. Impellizzeri, G.; Boninelli, S.; Priolo, F.; Napolitani, E.; Spinella, C.; Chroneos, A.; Bracht, H. Fluorine effect on As diffusion in Ge. J. Appl. Phys. 2011, 109, 113527. [CrossRef]

70. Jung, W.S.; Park, J.H.; Nainani, S.; Nam, D.; Saraswat, K.C. Fluorine passivation of vacancy defects in bulk germanium for Ge metal oxide semiconductor field effect transistor application. Appl. Phys. Lett. 2012, 101, 072104. [CrossRef]

71. Sanson, A.; El Mubarek, H.A.W.; Gandy, A.S.; De Salvador, D.; Napolitani, E.; Carnera, A. Formation of $\mathrm{F}_{6} \mathrm{~V}_{2}$ complexes in F-implanted Ge determined by X-ray absorption near edge structure spectroscopy. Mater. Sci. Semicond. Process. 2017, 62, 205-208. [CrossRef]

72. Boninelli, S.; Impellizzeri, G.; Priolo, F.; Napolitani, E.; Spinella, C. Fluorine in Ge: Segregation and EOR defects stabilization. Nucl. Instrum. Methods Phys. Res. Sect. B 2012, 282, 21-24. [CrossRef]

73. Edwardson, C.J.; Coleman, P.G.; El Mubarek, H.A.W. Positron annihilation studies of fluorine-vacancy complexes in phosphorus and fluorine implanted germanium. Semicond. Sci. Technol. 2014, 29, 035005. [CrossRef]

74. Granqvist, C.G. Handbook of Inorganic Electrochromic Materials; Elsevier: New York, NY, USA, 1995. 
75. Vasilopoulou, M.; Palilis, L.C.; Georgiadou, D.G.; Douvas, A.M.; Argitis, P.; Kennou, S.; Sygellou, L.; Papadimitropoulos, G.; Kostis, I.; Stathopoulos, N.A.; et al. Reduction of tungsten oxide: A path towards dual functionality utilization for efficient anode and cathode interfacial layers in organic light emitting diodes. Adv. Funct. Mater. 2011, 21, 1489-1497. [CrossRef]

76. Zhu, J.; Vasilopoulou, M.; Davazoglou, D.; Kennou, S.; Chroneos, A.; Schwingenschlögl, U. Intrinsic defects and $\mathrm{H}$ doping in $\mathrm{WO}_{3}$. Sci. Rep. 2017, 7, 40882. [CrossRef] [PubMed]

77. Deb, S.K. Optical and photoelectric properties and color centers in thin films of tungsten oxide. Philos. Mag. 1973, 27, 801-822. [CrossRef]

78. Owen, J.F.; Teegarden, K.J.; Shanks, H.R. Optical properties of the sodium-tungsten bronzes and tungsten trioxide. Phys. Rev. B 1978, 18, 3827-3837. [CrossRef]

79. Chen, X.; Liu, L.; Yu, P.Y.; Mao, S.S. Increasing solar absorption for photocatalysis with black hydrogenated titanium dioxide nanocrystals. Science 2011, 331, 746-750. [CrossRef] [PubMed]

80. Gerosa, M.; Valentin, C.D.; Onida, G.; Bottani, C.E.; Pacchioni, G. Anisotropic effects of oxygen vacancies on electrochromic properties and conductivity of $\gamma$-monoclinic $\mathrm{WO}_{3}$. J. Phys. Chem. C 2016, 120, 11716-11726. [CrossRef]

81. Wang, W.; Janotti, A.; Van de Walle, C.G. Role of oxygen vacancies in crystalline $\mathrm{WO}_{3}$. J. Mater. Chem. C 2016, 4, 6641-6648. [CrossRef]

82. Wang, F.; Di Valentin, C.; Pacchioni, G. Electronic and structural properties of $\mathrm{WO}_{3}$ : A systematic hybrid DFT study. J. Phys. Chem. C 2011, 115, 8345-8353. [CrossRef]

83. Fujishima, A.; Honda, K. Electrochemical photolysis of water at a semiconductor electrode. Nature 1972, 238, 37-38. [CrossRef] [PubMed]

84. Gratzel, M. Photoelectrochemical cells. Nature 2001, 414, 338-344. [CrossRef] [PubMed]

85. Asahi, R.; Morikawa, T.; Ohwaki, T.; Aoki, K.; Taga, Y. Visible-light photocatalysis in nitrogen-doped titanium oxides. Science 2001, 293, 269-271. [CrossRef] [PubMed]

86. Khan, S.U.M.; Al-Shahry, M.; Ingler, W.B. Efficient photochemical water splitting by a chemically modified $\mathrm{n}-\mathrm{TiO}_{2}$. Science 2002, 297, 2243-2245. [CrossRef] [PubMed]

87. Russo, S.P.; Grey, I.E.; Wilson, N.C. Nitrogen/hydrogen codoping of anatase: A DFT study. J. Phys. Chem. C 2008, 112, 7653-7664. [CrossRef]

88. Yang, H.G.; Sun, C.H.; Qiao, S.Z.; Zou, J.; Liu, G.; Smith, S.C.; Cheng, H.M.; Lu, G.Q. Anatase TiO 2 single crystals with a large percentage of reactive facets. Nature 2008, 453, 638-641. [CrossRef] [PubMed]

89. Gai, Y.; Li, J.; Li, S.-S.; Xia, J.-B.; Wei, S.-H. Design of narrow-gap $\mathrm{TiO}_{2}$ : A passivated codoping approach for enhanced photoelectrochemical activity. Phys. Rev. Lett. 2009, 102, 036402. [CrossRef] [PubMed]

90. Vasilopoulou, M.; Georgiadou, D.G.; Soultati, A.; Boukos, N.; Gardelis, S.; Palilis, L.C.; Fakis, M.; Skoulatakis, G.; Kennou, S.; Botzakaki, M.; et al. Atomic layer deposited aluminium and zirconium oxides for surface passivation of $\mathrm{TiO}_{2}$ in high-efficiency organic photovoltaics. Adv. Energy Mater. 2014, 4, 1400214. [CrossRef]

91. Sivula, K.; van de Krol, R. Semiconducting materials for photoelectrochemical energy conversion. Nat. Mater. Rev. 2016, 1, 15010. [CrossRef]

92. Khaselev, O.; Turner, J.A. A monolithic photovoltaic-photoelectrochemical device for hydrogen production via water splitting. Science 1998, 280, 425-427. [CrossRef] [PubMed]

93. Zhu, W.G.; Qiu, X.F.; Iancu, V.; Chen, X.Q.; Pan, H.; Wang, W.; Dimitrijevic, N.M.; Rajh, T.; Meyer, H.M.; Paranthaman, M.P.; et al. Band gap narrowing of titanium oxide semiconductors by noncompensated anion-cation codoping for enhanced visible-light photoactivity. Phys. Rev. Lett. 2009, 103, 226401. [CrossRef] [PubMed]

94. Yin, W.J.; Tang, H.W.; Wei, S.H.; Al-Jassim, M.M.; Turner, J.; Yan, Y.F. Band structure engineering of semiconductors for enhanced photochemical water splitting: The case of $\mathrm{TiO}_{2}$. Phys. Rev. B 2010, 82, 045106. [CrossRef]

95. Long, R.; English, N.J. Synergistic effects on band gap narrowing in titania by codoping from first principles calculations. Chem. Mater. 2010, 22, 1616-1623. [CrossRef]

96. Liao, P.L.; Carter, E.A. New concepts and modelling strategies to design and evaluate photoelectrocatalysis based on transition metal oxides. Chem. Soc. Rev. 2013, 42, 2401-2422. [CrossRef] [PubMed] 
97. Sun, Q.B.; Cortie, D.; Zhang, S.Y.; Frankcombe, T.J.; She, G.W.; Gao, J.; Sheppard, L.R.; Hu, W.B.; Chen, H.; Zhuo, S.J.; et al. The formation of defect-pairs for highly efficient visible light catalysts. Adv. Mater. 2017, 29, 1605123. [CrossRef] [PubMed]

98. Pan, H.; Zhang, Y.-W.; Shenoy, V.B.; Gao, H. Effects of H-, N-, and (H, N)-doping on the photocatalytic activity of $\mathrm{TiO}_{2}$. J. Phys. Chem. C 2011, 115, 12224-12231. [CrossRef]

99. Kobayashi, Y.; Hernandez, O.J.; Sakaguchi, T.; Yajima, T.; Roisnel, T.; Tsujimoto, Y.; Morita, M.; Noda, Y.; Mogami, Y.; Kitada, A.; et al. An oxyhydride of $\mathrm{BaTiO}_{3}$ exhibiting hydride exchange and electronic conductivity. Nat. Mater. 2012, 11, 507-511. [CrossRef] [PubMed]

100. Ma, X.; Dai, Y.; Yu, L.; Huang, B. Noble-metal-free plasmonic photocatalyst: Hydrogen doped semiconductors. Sci. Rep. 2014, 4, 3986. [CrossRef] [PubMed]

101. Van de Walle, C.G.; Neugebauer, J. Universal alignment of hydrogen levels in semiconductors, insulators and solutions. Nature 2003, 423, 626-628. [CrossRef] [PubMed]

102. Janotti, A.; Van de Walle, C.G. Hydrogen multicentre bonds. Nat. Mater. 2007, 6, 44-47. [CrossRef] [PubMed]

103. Varotsos, P. Calculation of the migration volume of vacancies in ionic solids from macroscopic parameters. Phys. Status Solidi A 1978, 47, K133-K136. [CrossRef]

104. Varotsos, P.; Alexopoulos, K. Thermodynamics of Point Defects and Their Relation with the Bulk Properties; North-Holland: Amsterdam, The Netherlands, 1986.

105. Zhang, B.; Wu, X.; Xu, J.; Zhou, R. Application of the $\mathrm{cB} \Omega$ model for the calculation of oxygen self-diffusion coefficients in minerals. J. Appl. Phys. 2010, 108, 053505. [CrossRef]

106. Vallianatos, F.; Saltas, V. Application of the $c B \Omega$ model to the calculation of diffusion parameters of He in olivine. Phys. Chem. Miner. 2014, 41, 181-188. [CrossRef]

107. Cooper, M.W.D.; Grimes, R.W.; Fitzpatrick, M.E.; Chroneos, A. Modeling oxygen self-diffusion in $\mathrm{UO}_{2}$ under pressure. Solid State Ionics 2015, 282, 26-30. [CrossRef]

108. Zhang, B.; Shan, S. Application of the $c B \Omega$ model to the calculation of diffusion parameters of Si in silicates. Geochem. Geophys. Geosyst. 2015, 16, 705-718. [CrossRef]

109. Chroneos, A.; Vovk, R.V. Modeling self-diffusion in $\mathrm{UO}_{2}$ and $\mathrm{ThO}_{2}$ by connecting point defect parameters with bulk properties. Solid State Ionics 2015, 274, 1-3. [CrossRef]

110. Chroneos, A.; Vovk, R.V. Connecting bulk properties of germanium with the behavior of self- and dopant diffusion. Mater. Sci. Semicond. Proc. 2015, 36, 179-183. [CrossRef]

111. Chroneos, A.; Fitzpatrick, M.E.; Tsoukalas, L.H. Describing oxygen self-diffusion in $\mathrm{PuO}_{2}$ by connecting point defect parameters with bulk properties. J. Mater. Sci. Mater. Electron. 2015, 26, 3287-3290. [CrossRef]

112. Ganniari-Papageorgiou, E.; Fitzpatrick, M.E.; Chroneos, A. Germanium diffusion in aluminium: connection between point defect parameters with bulk properties. J. Mater. Sci. Mater. Electron. 2015, 26, 8421-8424. [CrossRef]

113. Chroneos, A.; Vovk, R.V. Modeling indium diffusion in germanium by connecting point defect parameters with bulk properties. J. Mater. Sci. Mater. Electron. 2015, 26, 2113-2116. [CrossRef]

114. Parfitt, D.C.; Cooper, M.W.D.; Rushton, M.J.D.; Christopoulos, S.-R.G.; Fitzpatrick, M.E.; Chroneos, A. Thermodynamic calculations of oxygen self-diffusion in mixed-oxide nuclear fuels. RSC Adv. 2016, 6, 74018-74028. [CrossRef]

115. Saltas, V.; Chroneos, A.; Vallianatos, F.A. A thermodynamic approach of self- and hetero-diffusion in GaAs: Connecting point defect parameters with bulk properties. RSC Adv. 2016, 6, 53324-53330. [CrossRef]

116. Chroneos, A. Connecting point defect parameters with bulk properties to describe diffusion in solids. Appl. Phys. Rev. 2016, 3, 041304. [CrossRef]

117. Saltas, V.; Chroneos, A.; Vallianatos, F.A. A thermodynamic approach to self-diffusion in silicon: Evidence of a single diffusion mechanism? Mater. Chem. Phys. 2016, 181, 204-208. [CrossRef]

118. Sarlis, N.V.; Skordas, E.S. Estimating the compressibility of osmium from recent measurements of Ir-Os alloys under high pressure. J. Phys. Chem. A 2016, 120, 1601-1604. [CrossRef] [PubMed]

119. Saltas, V.; Chroneos, A.; Vallianatos, F.A. Composition and temperature dependence of self-diffusion in $\mathrm{Si}_{1-x} \mathrm{Ge}_{x}$ alloys. Sci. Rep. 2017, 7, 1374. [CrossRef] [PubMed]

(C) 2017 by the authors. Licensee MDPI, Basel, Switzerland. This article is an open access article distributed under the terms and conditions of the Creative Commons Attribution (CC BY) license (http://creativecommons.org/licenses/by/4.0/). 